\title{
TREATMENT APPROACH TO FOLLICULAR THYROID CARCINOMA TUMOR THROMBUS IN THE INTERNAL JUGULAR VEIN AND BRACHIOCEPHALIC VEIN
}

\author{
Zaviša Čolović ${ }^{1}$, Petar Ivanišević ${ }^{1}$, Cristijan Bulat ${ }^{2}$, Ana Barić ${ }^{3}$, Mirko Kontić ${ }^{1}$, \\ Hrvoje Punda ${ }^{4}$, Nikola Kolja Poljak ${ }^{1}$ and Ante Punda ${ }^{3}$
}

${ }^{1}$ University of Split, Split University Hospital Center, Department of Otorhinolaryngology, Spinčićeva 1, Split, Croatia; ${ }^{2}$ University of Split, Split University Hospital Center, Department of Cardiac Surgery, Spinčićeva 1, Split, Croatia; ${ }^{3}$ University of Split, Split University Hospital Center, Department of Nuclear Medicine, Spinčićeva 1, Split, Croatia; ${ }^{4}$ University of Split, Split University Hospital Center, Department of Radiology, Spinčićeva 1, Split, Croatia

SUMMARY - Thyroid gland carcinoma causing tumor thrombus in the great veins of the neck and mediastinum is a rare condition with poor prognosis. Invasion of the internal jugular vein by thyroid gland carcinoma has been occasionally reported, but tumor thrombi extending to the great veins of the mediastinum are reported extremely rarely. We present a treatment approach in a case of follicular thyroid carcinoma intravascular tumor thrombus in the left internal jugular and left brachiocephalic vein.

Key words: intravascular tumor thrombus, follicular thyroid carcinoma, internal jugular vein, brachiocephalic vein.

\section{Introduction}

Differentiated thyroid carcinoma (DTC), which includes papillary, follicular, and Hürthle cell carcinoma comprises the vast majority (90\%) of all thyroid cancers $^{1,2}$. Follicular thyroid carcinoma (FTC) is the second most common thyroid malignancy and accounts for approximately $10 \%$ of all thyroid malignancies $^{3}$.

FTC tends to invade blood vessels and metastasize by hematogenous spread to distant sites, most commonly to the bones and lungs. The incidence of distant metastasis in FTC has been reported as 6-20\%4.

However, cases with massive angio-invasion are rare $^{5}$.

Metastasis to the internal jugular vein (IJV) from a thyroid malignancy is not common ${ }^{3}$.

Corresponding author: Dr. Petar Ivaniševiç, $M D$, University of Split, University Hospital Center Split, Department of Otorhinolaryngology, Split, Croatia, Spinčićeva 1, 21000 Split, Croatia

E-mail: pivanisevic@kbsplit.hr
Tumor thrombus occurs by direct extension or by occult vascular spread. The tumor invades the internal jugular vein through the thyroid veins and propagates ${ }^{6}$.

When there is involvement of the superior vena cava and the right atrium, we usually call it superior vena cava syndrome ${ }^{7}$.

\section{Case report}

A 67-year-old male patient was hospitalized at the ENT Department of the Split University Hospital.

The reason for hospitalization was a surgery of the follicular thyroid carcinoma tumor thrombus in the residual distal part of the left internal jugular vein and left brachiocephalic vein.

Total thyroidectomy with left-sided modified radical neck dissection with resection of the left internal jugular vein was performed, with postoperative radioiodine ablation (RAI) six months prior the present hospitalization.

Pathohistology findings showed a wide invasive oncocyte type of follicular thyroid carcinoma, negative 
borders, vascular invasion, and a thrombosed internal jugular vein (organized tumor thrombus $13 \mathrm{~mm}$ in diameter).

Postoperative RAI (I-131, $150 \mathrm{mCi}$ ) was performed at the Department of Nuclear Medicine, Split University Hospital.

Six months after surgery, ultrasound (US) of the neck showed a hypoechoic nodule $25 \times 10.4 \times 16.7$ $\mathrm{mm}$ in the left supraclavicular region, in the deep distal part of left neck region IV, situated deeply and behind the sternoclavicular joint.

Fine-needle aspiration (FNA) under US guidance showed a follicular thyroid tumor.

MSCT of the neck and thorax were negative, without signs of tumor recurrence.

MSCT angiography was also without signs of intravascular thrombus in the large vessels of the neck and mediastinum.

Despite the fact that neither MSCT of the neck and thorax nor MSCT angiography identified intravascular tumor thrombus in the large blood vessels of the neck and thorax, we decided to perform the surgery. This was because an organized tumor thrombus was found in the left internal jugular vein in the pathohistological report after the first operation and due to the fact that the FNA was performed deep and behind the sternoclavicular joint, on the verge of transcervical feasibility, and the observation of the cytologist who performed the FNA was that the needle punctuated something of an unusually soft consistency as opposed to a more consistent metastatic lymph node. In collaboration with a cardiothoracic surgeon, we decided to approach to surgery with the assumption that there was a possible metastatic tumor thrombus in the residual distal part of the left internal jugular vein with possible distal extension into the left brachiocephalic vein, and that sternotomy will thus be needed as an adequate approach.

After these new findings, transcervical exploration of the left neck regions IV, VI, and VII with exploration of the residual distal part of the left internal jugular vein, a trans-partial sternotomy approach, and extirpation of the intravascular tumor thrombus (thrombectomy) from the residual distal part of the left internal jugular which extends to the left brachiocephalic vein was performed via minimum phlebotomy (Figure 1). After thrombectomy, the left brachiocephalic vein was sutured and reconstructed primarily.

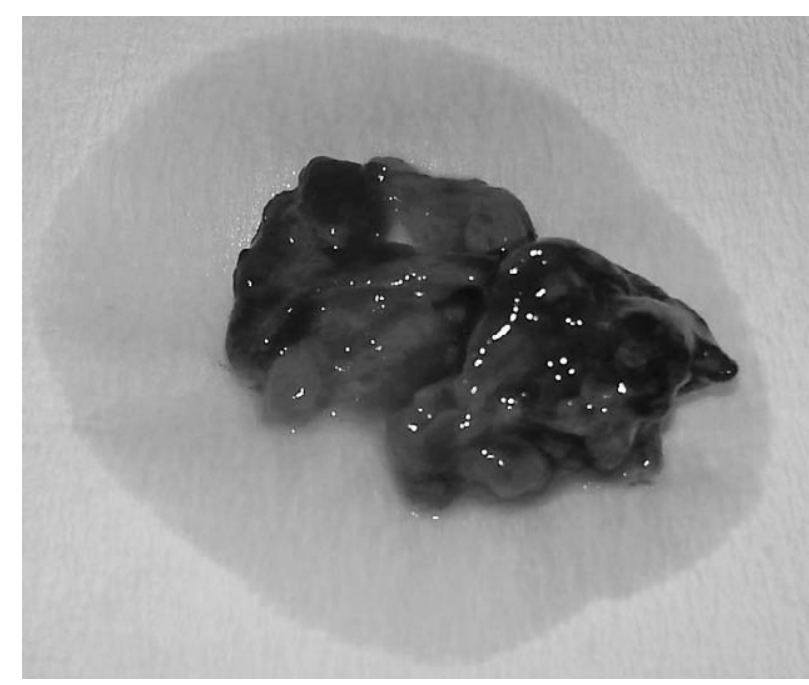

Figure 1. Intravascular tumor thrombus of follicular thyroid carcinoma

Pathohistology findings showed an intravascular tumor thrombus of follicular thyroid carcinoma.

After the surgery, the patient was also treated with RAI (I-131, 30.9 mCi).

\section{Discussion}

Thyroid gland cancer causing tumor thrombus in the great veins of the neck and mediastinum is a rare condition with poor prognosis ${ }^{5}$. Solitary internal jugular vein invasion by thyroid cancer has been occasionally reported, but tumor thrombi extending to the great veins of the mediastinum are extremely rare. Surgical treatment in collaboration between ENT and cardiothoracic surgeons is necessary in such cases 5 .

We report a case of 67-year-old patient who had surgical treatment and postoperative RAI of follicular thyroid carcinoma tumor thrombus in the internal jugular vein and brachiocephalic vein.

Preoperative diagnostic imaging is important. CT and ultrasonography have been reported to be useful for detecting tumor thrombi of thyroid malignancies ${ }^{5}$.

Fluoro-18 fluorodeoxyglucose positron emission tomography/computerized tomography (18F-FDG$\mathrm{PET} / \mathrm{CT}$ ) is useful in detecting tumor thrombi and discriminating them from clots of other etiology ${ }^{7}$.

Taib and Hisham described the importance of the positive ring sign, which is a rim of contrast around the tumor thrombus on CT examination ${ }^{8}$. 
The ring sign indicates that the thrombus is not adherent or invading into the endothelium lining of the great veins ${ }^{9}$.

When vascular invasion is identified in FTCs, number of vessels involved is of prognostic significance ( $<4$ or $\geq 4$ vascular invasions $)^{10}$.

Thompson et al. reported the first case in which follicular thyroid gland carcinoma with extensive tumor thrombus in the mediastinum great veins was treated ${ }^{9}$.

Nakashima et al. reported a case of a 54-year-old patient who had extensive invasion into both internal jugular veins, the brachiocephalic vein, and the superior vena cava. CT revealed tumor thrombi. The patient was treated with surgery followed by radiation therapy ${ }^{5}$.

Özülker et al. reported a case of a tumor thrombus in the left brachiocephalic vein, the superior vena cava, and the right atrium in a 45-year-old male patient with metastatic follicular thyroid cancer ${ }^{7}$.

Taib and Hisham presented 3 cases of follicular thyroid cancer with tumor extension into the great cervical veins and right atrium ${ }^{8}$.

Do Nascimento et al. described a patient with follicular thyroid cancer submitted to total thyroidectomy. SPECT/CT images demonstrated a potential thrombus in the left jugular vein (confirmed by doppler neck ultrasound and MRI). The thrombectomy was performed, and pathohistology confirmed metastasis of follicular carcinoma ${ }^{11}$.

Onoda et al. reported a case of advanced follicular thyroid carcinoma with massive involvement of the great veins of the neck and mediastinum and an extensive tumor thrombus growing intraluminally into the superior vena cava ${ }^{12}$.

In our case, we used a combination of a transcervical and partial sternotomy approach to remove the tumor thrombus from the residual distal part of the left internal jugular vein, which had propagated into the left brachycephalic vein from which the tumor thrombus was removed via minimum phlebotomy. After thrombectomy, the left brachiocephalic vein was sutured and reconstructed primarily.

\section{Conclusion}

We report a rare case of follicular thyroid carcinoma tumor thrombus in the internal jugular vein and brachiocephalic vein. Preoperative evaluation by ap- propriate diagnostic tools is important for planning the treatment strategy. The patient was treated with surgery and postoperative RAI therapy.

\section{References}

1. Curic Radivojevic R, Prgomet D, Markesic J, Ezgeta C. Hypocalcaemia after thyroid surgery for differentiated thyroid carcinoma: preliminary study report. Coll Antropol. 2012;36 (Supp12):73-8.

2. Kusić Z, Prgomet D. Tumori šitnjače i doštitne žlijezde. In: Prgomet. Tumori glave i vrata. Zagreb: Medicinska naklada; 2019. p. 262-277.

3. Choi SH, Chung KW, Min HS, Kim EK. Intravascular Metastasis at the Internal Jugular Vein From Follicular Thyroid Carcinoma. J Ultrasound Med. 2010;29:659-62. doi: 10.7863/ jum.2010.29.4.659.

4. Parameswaran R, Shulin Hu J, Min En N, Tan WB, Yuan NK. Patterns of metastasis in follicular thyroid carcinoma and the difference between early and delayed presentation. Ann R Coll Surg Engl. 2017;99:151-4. doi: 10.1308/rcsann.2016.0300.

5. Nakashima T, Nakashima A, Murakami D, Toh S, Shiratsuchi $\mathrm{H}$, Yasumatsu $\mathrm{R}$ et al. Follicular carcinoma of the thyroid with massive invasion into the cervical and mediastinum great veins: our own experience and literature review. Laryngoscope. 2012; 122:2855-7. doi: 10.1002/lary.23690.

6. Manik G, Jose J, Hygriv Rao B. Follicular thyroid carcinoma with tumour thrombus extending into superior vena cava and right atrium - A case report. Indian Heart J. 2016; 68(Supp12): 146-7. doi: 10.1016/j.ihj.2016.05.016.

7. Ozülker T, Ozülker F, Eker O, Ozpaçaci T, Ozcan D.Tumour thrombus from follicular thyroid cancer detected by $18 \mathrm{~F}$ FDG-PET/CT. Hell J Nucl Med. 2009;12:66-7.

8. Taib NA, Hisham AN.Follicular thyroid carcinoma with direct tumour extension into the great cervical veins and right atrium: is transcervical thrombectomy a safe option? Asian J Surg. 2007;30:216-9. doi: 10.1016/s1015-9584(08)60025-1.

9. Thompson NW, Brown J, Orringer M, Sisson J, Nishiyama R.Follicular carcinoma of the thyroid with massive angioinvasion: extension of tumor thrombus to the heart. Surgery. 1978; 83:451-7.

10. Lin X, Zhu B, Liu Y, Silverman JF.Follicular thyroid carcinoma invades venous rather than lymphatic vessels. Diagn Pathol. 2010;5:8. doi: 10.1186/1746-1596-5-8.

11. do Nascimento BB, de Sá Camargo Etchebehere EC, Montalli Assumpção LV, Tincani AJ, de Oliveira Santos A, Baracat $\mathrm{J}$ et al. Follicular thyroid carcinoma metastasis to the internal jugular vein demonstrated by 131I SPECT/CT. Clin Nucl Med. 2014;39:270-3. doi: 10.1097/RLU.0b013e3182952959.

12. Onoda N, Nakamura M, Hosono M, Sasaki Y, Kawajiri H, Takashima $\mathrm{T}$ et al. Successful surgical treatment of advanced follicular thyroid carcinoma with tumor thrombus infiltrating the superior vena cava: report of a case. Surg Today. 2012;42:18590. doi: 10.1007/s00595-011-0033-4. 


\section{Sažetak \\ PRISTUP LIJEČENJU TUMORSKOG TROMBA FOLIKULARNOG KARCINOMA ŠTITNJAČE U UNUTARNJOJ JUGULARNOJ I BRAHIOCEFALIČNOJ VENI \\ Zaviša Čolović, Petar Ivanišević, Cristijan Bulat, Ana Barić, Mirko Kontić, Hrvoje Punda, Nikola Kolja Poljak i Ante Punda}

Karcinom štitnjače koji uzrokuje tumorske trombe u velikim venama vrata i medijastinuma je rijedak i ima lošu prognozu. Invazija unutarnje jugularne vene karcinomom štitnjače se povremeno opisuje u člancima, ali tumorski trombi koji zahvaćaju velike vene medijastinuma su iznimno rijetko opisani.

Prikazujemo pristup liječenjuintravaskularnog tumorskog tromba folikularnog karcinoma štitnjače u lijevoj unutranjoj jugularnoj i lijevoj brahiocefaličnoj veni.

Ključne riječi: intravaskularni tumorski tromb, folikularni karcinom štitnjače, unutarnja jugularna vena, brabiocefalična vena. 